Journal of Applied Pharmaceutical Science Vol. 6 (09), pp. 140-146, September, 2016

Available online at http://www.japsonline.com

DOI: $10.7324 / \mathrm{JAPS} .2016 .60921$

ISSN 2231-3354 (cc) EY-NC-SA

\title{
Development of Validated Stability Indicating RP-HPLC-PDA Method for Camptothecin Analysis
}

\author{
Buchi N. Nalluri ${ }^{1,2^{*}}$, Saisrianusha Valluru ${ }^{1}$, Chandrapriyanka Bonthu ${ }^{2}$ \\ ${ }^{1}$ Department of Pharmaceutics, KVSR Siddhartha College of Pharmaceutical Sciences, Vijayawada, AP, India. \\ ${ }^{2}$ Department of Pharmaceutical Analysis, KVSR Siddhartha College of Pharmaceutical Sciences, Vijayawada, AP, India.
}

\begin{tabular}{l} 
ARTICLE INFO \\
\hline Article history: \\
Received on: 05/07/2016 \\
Revised on: 22/07/2016 \\
Accepted on: 19/08/2016 \\
Available online: 26/09/2016 \\
\hline Key words: \\
Camptothecin, Dissolution \\
sample analysis, PDA \\
(Photodiode array) Detection, \\
Stability Indicating Method, \\
Validation.
\end{tabular}

\section{INTRODUCTION}

Stability indicating methods have become an important aspect of analytical method validation and a part of US FDA requirements. CPT was discovered by Wall ME and Wani MC in 1966 by systematic screening of natural products for anticancer drugs (Wall and Wani, 1996; Wall et al., 1966). CPT being cytotoxic quinoline alkaloid inhibits DNA enzyme topoisomerase I showed remarkable anticancer activity against gastric carcinoma, hepatoma, leukemia and tumor of head and neck (Qing et al., 2006). Chemically, CPT (Fig. 1) is (S)-4-ethyl-4hydroxy-1H-pyrano[3',4':6,7]indolizino[1,2-b] quinoline-3,14$(4 \mathrm{H}, 12 \mathrm{H})$-dione.But therapeutic application of unmodified CPT is hindered by very low solubility in aqueous media, high toxicity, and rapid inactivation through lactone ring hydrolysis

\footnotetext{
* Corresponding Author

Buchi N. Nalluri, Department of Pharmaceutics, KVSR Siddhartha College of Pharmaceutical Sciences, Vijayawada, AP, INDIA Email:buchinalluri@yahoo.com
}

at physiological $\mathrm{pH}$. Lactone hydrolysis, which is reversible in acidic media, leads to a water-soluble carboxylate, inactive for cellular uptake (Chen et al., 2002). Several analytical methods were reported for the analysis of CPT and its analogues based on HPLC, mass spectroscopy, high pressure thin layer chromatography (HPTLC), thin layer chromatography (TLC), UVVisible Spectroscopy, UV-Resonance Raman Spectroscopy and Fluorescence Spectroscopy techniques in biological samples and also in some formulation works (Feofanov et al., 1996 ; Igor et al ., 1998; Indramohan et al., 2010; Jeffrey et al., 1991 ; Kruszewski et al., 2010; Marques FF et al., 2010; Namdeo et al., 2012 ; Paulo M et al., 2010; Qing et al., 2006 ; Sanna N et al., 2009 ; Srimany et al., 2011 ; Susan et al., 2012 ; Tsakalozou et al., 2010 ; Underberg et al., 1990; Venkateshwarlu et al., 2012; Vidya et al., 2007; Yong et al., 2006).

However, there is no stability indicating HPLC-PDA method published for the estimation of CPT in bulk, dosage form and in dissolution samples so far whereas stability indicating HPLC-PDA method (gradient) was reported for 10-Hydroxy Camptothecin (Venkateshwarlu et al., 2012). 
Hence, in this investigation an attempt was made to develop a simple, accurate stability indicating RP-HPLC isocratic method for the analysis of CPT in bulk, formulation and dissolution samples. The method was validated as per ICH guidelines (ICH, 2005).

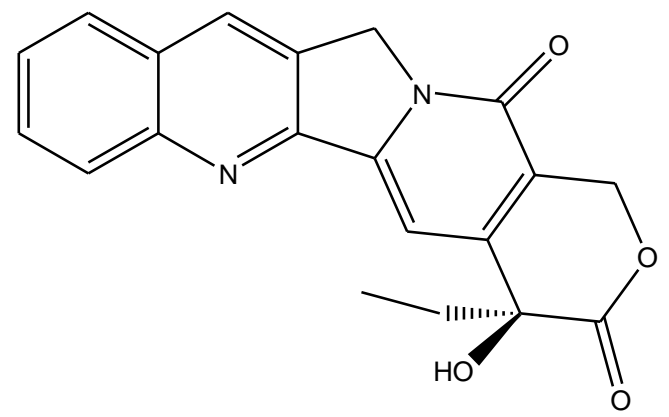

Fig. 1: Molecular structure of CPT

\section{MATERIALS AND METHODS}

\section{Reagents and chemicals}

CPT was supplied by Gamma Technology Development Co Ltd (Shenzhen, China). Water, Methanol, Acetonitrile, Ammonium acetate, Hydrochloric acid, Hydrogen peroxide are HPLC grade and Sodium hydroxide, Potassium chloride are of AR grade. All the solvents and reagents were purchased from E. Merck, Mumbai, India.

\section{Equipment}

Analysis was performed on Shimadzu Prominence HPLC system provided with DGU-20A3 degasser, LC-20AD binary pumps, SIL-20AHT auto sampler, and SPD-M20A PDA detector. Data acquisition was carried out using LC solutions software. The chromatographic separation was performed on Inertsil-ODS- $\mathrm{C}_{18}$ (250mm x 4.6mm, $5 \mu \mathrm{m}$ ) Column.

\section{Chromatographic Conditions}

Mobile phase consisting of $15 \mathrm{mM}$ ammonium acetate ( $\mathrm{pH}$ 6.5): acetonitrile (60:40) was used in isocratic mode and the mobile phase was filtered through nylon disc filter of $0.45 \mu \mathrm{m}$ (Millipore) and sonicated for $3 \mathrm{~min}$ before use. The flow rate was $1 \mathrm{~mL} / \mathrm{min}$ and the injection volume was $20 \mu \mathrm{L}$. PDA detection was performed at $254 \mathrm{~nm}$ and the separation was achieved at ambient temperature.

\section{Preparation of Stock Solution}

An accurately weighed quantity of $10 \mathrm{mg}$ of CPT was transferred to $10 \mathrm{~mL}$ volumetric flask and dissolved in and made up to volume with DMSO (Dimethyl sulfoxide) to give 1000 $\mu \mathrm{g} / \mathrm{mL}$ concentration.

\section{Validation}

Validation of the stability indicating method was carried out as per guidelines of ICH (ICH, 2005).

\section{System Suitability}

The system suitability of the method is determined by increasing the injection volume from 10 to $50 \mu \mathrm{L}$. The percentage relative standard deviation (\%RSD) of retention time and tailing factor are calculated.

\section{Specificity \\ Acid Hydrolysis}

$100 \mu \mathrm{L}$ of CPT stock solution $(1000 \mu \mathrm{g} / \mathrm{mL})$ was added to $900 \mu \mathrm{L}$ of $1 \mathrm{~N} \mathrm{HCl}$ and kept at $70^{\circ} \mathrm{C}$ for one week. This was further diluted with methanol (diluent) to get a final concentration of $10 \mu \mathrm{g} / \mathrm{mL}$.

\section{Base Hydrolysis}

$100 \mu \mathrm{L}$ of CPT stock solution $(1000 \mu \mathrm{g} / \mathrm{mL})$ was added to $900 \mu \mathrm{L}$ of $1 \mathrm{~N} \mathrm{NaOH}$ and kept at $70^{\circ} \mathrm{C}$ for one week. This was further diluted with methanol (diluent) to get a final concentration of $10 \mu \mathrm{g} / \mathrm{mL}$.

\section{Oxidation}

$100 \mu \mathrm{L}$ of CPT stock solution $(1000 \mu \mathrm{g} / \mathrm{mL})$ was added to $900 \mu \mathrm{L}$ of $3 \% \mathrm{H}_{2} \mathrm{O}_{2}$ and was kept at $70^{\circ} \mathrm{C}$ for one week. This was further diluted with methanol (diluent) to get a final concentration of $10 \mu \mathrm{g} / \mathrm{mL}$.

\section{Thermal Degradation}

About 5mg of CPT was weighed accurately and kept at $70^{\circ} \mathrm{C}$ for one week. Then solution was prepared with DMSO and diluted with methanol to achieve a final concentration of $10 \mu \mathrm{g} / \mathrm{mL}$.

\section{Thermal and Humidity}

An accurately weighed quantity of CPT kept for 1 week at $70^{\circ} \mathrm{C}$ in a desiccator filled with saturated potassium chloride solution that gives $75 \%$ relative humidity. Then solution was prepared with DMSO and diluted with methanol to achieve a final concentration of $10 \mu \mathrm{g} / \mathrm{mL}$.

\section{Photo degradation}

An accurately weighed quantity of CPT was exposed to UV light for one week. Then solution was prepared with DMSO and diluted with methanol to achieve a final concentration of $10 \mu \mathrm{g} / \mathrm{mL}$

\section{Linearity}

The linearity of CPT responses was determined by preparing and injecting standard solutions in the concentration range of $2-10 \mu \mathrm{g} / \mathrm{mL}$. 


\section{Precision}

Precision was measured in terms of repeatability of application and measurement and this study was carried out by injecting six replicates of the same standard (system precision) at a concentration of $10 \mu \mathrm{g} / \mathrm{mL}$.

\section{Accuracy}

Accuracy (recovery) of the method was tested by spiking 75,100 and $125 \%$ of CPT at $4 \mu \mathrm{g} / \mathrm{mL}$ concentration. The accuracy of the analytical method was established in triplicate across its range according to the assay procedure.

\section{Robustness}

By introducing small but deliberate changes in flow rate $( \pm 5.0 \%)$, mobile phase composition and wave length, robustness of the described method was studied. The robustness of the method was assessed for $10 \mu \mathrm{g} / \mathrm{mL}$ concentration.

\section{LOD and LOQ}

The sensitivity of the method was determined with respect to LOD and LOQ. The LOD and LOQ were separately determined based on the standard calibration curve. LOD and LOQ were calculated by using following formulae: $\mathrm{LOD}=(3.3$ $\times \sigma) / \mathrm{m}$; $\mathrm{LOQ}=(10.0 \times \sigma) / \mathrm{m}$ (Where, $\sigma$ is the standard deviation of the responses and $\mathrm{m}$ is mean of the slopes of the calibration curves).

\section{Assay}

Twenty tablets were weighed individually and finely powdered. The powder equivalent to $10 \mathrm{mg}$ of CPT was accurately weighed and transferred to a $10 \mathrm{~mL}$ volumetric flask and $5 \mathrm{~mL}$ of DMSO was added to the same. The flask was sonicated for $5 \mathrm{~min}$ and volume was made up to the mark with DMSO. The above solution was filtered using nylon disposable syringe filter $(13 \mathrm{~mm}$, $0.45 \mu \mathrm{m}$ ) and the $100 \mu \mathrm{L}$ of the filtrate was diluted to $10 \mathrm{~mL}$ with diluent. The amount present in the each tablet was calculated by comparing the area of standard CPT with that of the tablet sample.

\section{Filter Compatibility Study}

Dissolution samples were checked for compatibility with both the nylon filter $(0.45 \mu \mathrm{m})$ and Polyvinylidene Difluoride (PVDF) filters $(0.45 \mu \mathrm{m})$. CPT standard in dissolution medium was prepared and the solution was filtered through the both filters. Both the filtered and unfiltered standard samples were injected.

\section{Dissolution Sample Analysis}

Dissolution of CPT controlled release tablets (prepared in house) was performed using USP type-2 (paddle) dissolution test apparatus. Tablets were placed in sinkers and dropped in to the dissolution vessel containing $900 \mathrm{~mL}$ of $0.1 \mathrm{~N} \mathrm{HCl}$ with $3 \%$ SLS as dissolution medium. The temperature of the medium at $37 \pm 0.5^{\circ} \mathrm{C}$ and $100 \mathrm{rpm}$ was maintained. Samples were withdrawn at predetermined time intervals. Samples were filtered $(0.45 \mu \mathrm{m}$ nylon disc filter) and were suitably diluted with methanol and subjected to HPLC analysis.

\section{RESULTS AND DISCUSSION}

CPT is an oral anti neoplastic drug used to treat cancer. Literature survey reveals that there is no stability indicating HPLC method reported so far for the analysis of CPT in bulk, formulation and dissolution sample analysis. Keeping this point into consideration, an attempt was made to develop a simple and accurate RP-HPLC isocratic method to determine CPT in the presence of its degradation products. Initial trail was carried out with phenomenex $\mathrm{C}_{18}$ column $(150 \times 4.6 \mathrm{~mm}, 5 \mu)$ using a mobile phase of Formic acid $(0.05 \% \mathrm{v} / \mathrm{v})$ : acetonitrile (70:30) at a flow rate of $1 \mathrm{~mL} / \mathrm{min}$ which produced an asymmetric peak with retention time $\left(\mathrm{R}_{\mathrm{t}}\right)$ of 6.91 .

In trail 2, mobile phase composition of Formic acid $(0.05 \% \mathrm{v} / \mathrm{v})$ : methanol (30:70) is used, a symmetric peak with more band width and $\mathrm{R}_{\mathrm{t}}$ of 4.83 was observed. Therefore, in trail-3 mobile phase composition was changed to Formic acid $(0.05 \% \mathrm{v} / \mathrm{v})$ : acetonitrile $(25: 75)$, peak eluted at $2.42 \mathrm{~min}$ but peak shape and symmetry were not good. In the next trail mobile phase composition used was Formic acid $(0.05 \% \mathrm{v} / \mathrm{v})$ : acetonitrile (50:50) but peak shape and symmetry were not good and CPT peak eluted at $4.25 \mathrm{~min}$ along with solvent peak. In order to improve the peak resolution and symmetry the next trail was performed by increasing the flow rate to $1.2 \mathrm{~mL} / \mathrm{min}$ and changing the mobile phase composition to Formic acid $(0.05 \% \mathrm{v} / \mathrm{v})$ : acetonitrile (60:40). Under these conditions, CPT eluted at $2.83 \mathrm{~min}$, the peak shape and symmetry were better but not suitable for stability indicating method as resolution may not be obtained in the presence of hydrophilic degradants.

Further trails were performed using mobile phase composition of $15 \mathrm{mM}$ Ammonium acetate: acetonitrile (60:40), column used was Inertsil $\mathrm{C}_{18}(250 \times 4.6 \mathrm{~mm}, 5 \mu)$, and acetonitrile as diluent. In this trail peak eluted at 6.68 and symmetry is good but still band width is more. In the next trail methanol was used as diluent keeping the other entire parameters similar to above trail. This produced a peak with good shape and symmetry (tailing factor 1.14) and retention time of $6.8 \mathrm{~min}$ at a flow rate of 1 $\mathrm{mL} / \mathrm{min}$ with UV detector at $254 \mathrm{~nm}$. The run time was set at 10 min and ambient temperatures for the HPLC system and was found to be the best for the analysis. The chromatogram of standard CPT is shown in the Fig. 2 along with peak purity index and UV spectrum. The peak purity index was found to be greater than 0.9999 indicating peak purity of the CPT samples used in the analysis.

\section{Validation}

Validation of an analytical procedure is the process by which it is established, by laboratory studies, that the performance characteristics of the procedure meet the requirements for the intended analytical applications. 

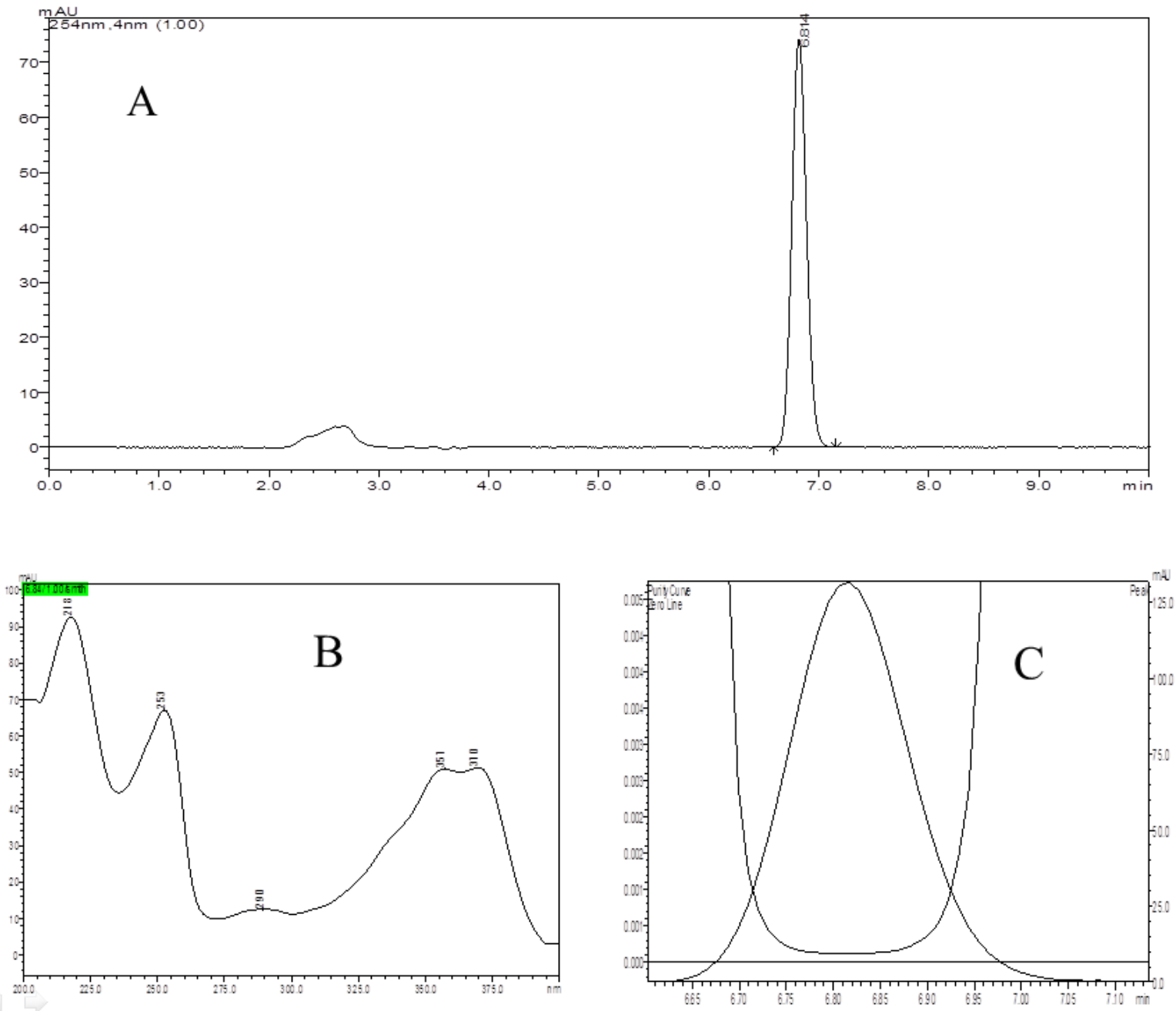

Fig. 2: (A) CPT Standard chromatogram, (B) UV Spectrum, (C) Peak purity profile

\section{System Suitability}

System suitability studies were carried out by injecting a $10 \mu \mathrm{g} / \mathrm{mL}$ standard of CPT at different injection volumes in the range of $10-50 \mu \mathrm{L}$. The $\% \mathrm{RSD}$ values for retention time and tailing factor were 0.131 and 0.53 respectively.

\section{Specificity}

\section{Forced degradation studies}

Degradation was not observed in CPT stressed samples that were subjected to heat, light and heat/humidity. However, degradation was observed under acid hydrolysis, base hydrolysis and oxidative conditions. The CPT was completely degraded in oxidative and base hydrolysis. Acid hydrolysis resulted in degradation peaks with retention times $(\mathrm{min})$ at $3.55,5.63,8.86$, and 11.72. Base hydrolysis resulted in degradation peaks with retention times $(\mathrm{min})$ at $5.20,6.10,7.40$, and 11.31 . Oxidative hydrolysis resulted in peaks with retention times (min) at 3.58 ,
8.16. No thermal, thermal/humidity and photo degradation of CPT was observed. The peak purity test results derived from PDA detection confirmed that the CPT peaks were pure in the acid hydrolysis, thermal, thermal/humidity and light degradation analyzed stress condition samples. These results indicate that the developed HPLC method was specific and stability-indicating. The stability data was given in the Table I and chromatograms were shown in the Fig. 3.

Table I: Forced Degradation Studies Data.

\begin{tabular}{lcc}
\hline Degradation Condition & $\begin{array}{c}\text { \% CPT } \\
\text { Peak } \\
\text { Area }\end{array}$ & $\begin{array}{c}\text { Peak } \\
\text { Purity }\end{array}$ \\
\hline $1 \mathrm{~N} \mathrm{HCl}$ at $70^{\circ} \mathrm{C}$ for $1 \mathrm{Week}$ & 37.21 & Pass \\
$1 \mathrm{~N} \mathrm{NaOH}$ at $70^{\circ} \mathrm{C}$ for $1 \mathrm{Week}$ & - & - \\
$3 \% \mathrm{H}_{2} \mathrm{O}_{2}$ at $70^{\circ} \mathrm{C}$ for $1 \mathrm{Week}$ & - & - \\
Thermal at $70^{\circ} \mathrm{C}$ for $1 \mathrm{Week}$ & 100 & Pass \\
Thermal $/ \mathrm{Humidity}$ at $70^{\circ} \mathrm{C} / 75 \% \mathrm{RH}$ for $1 \mathrm{Week}$ & 100 & Pass \\
UV Light for $1 \mathrm{Week}$ & 100 & Pass \\
\hline
\end{tabular}



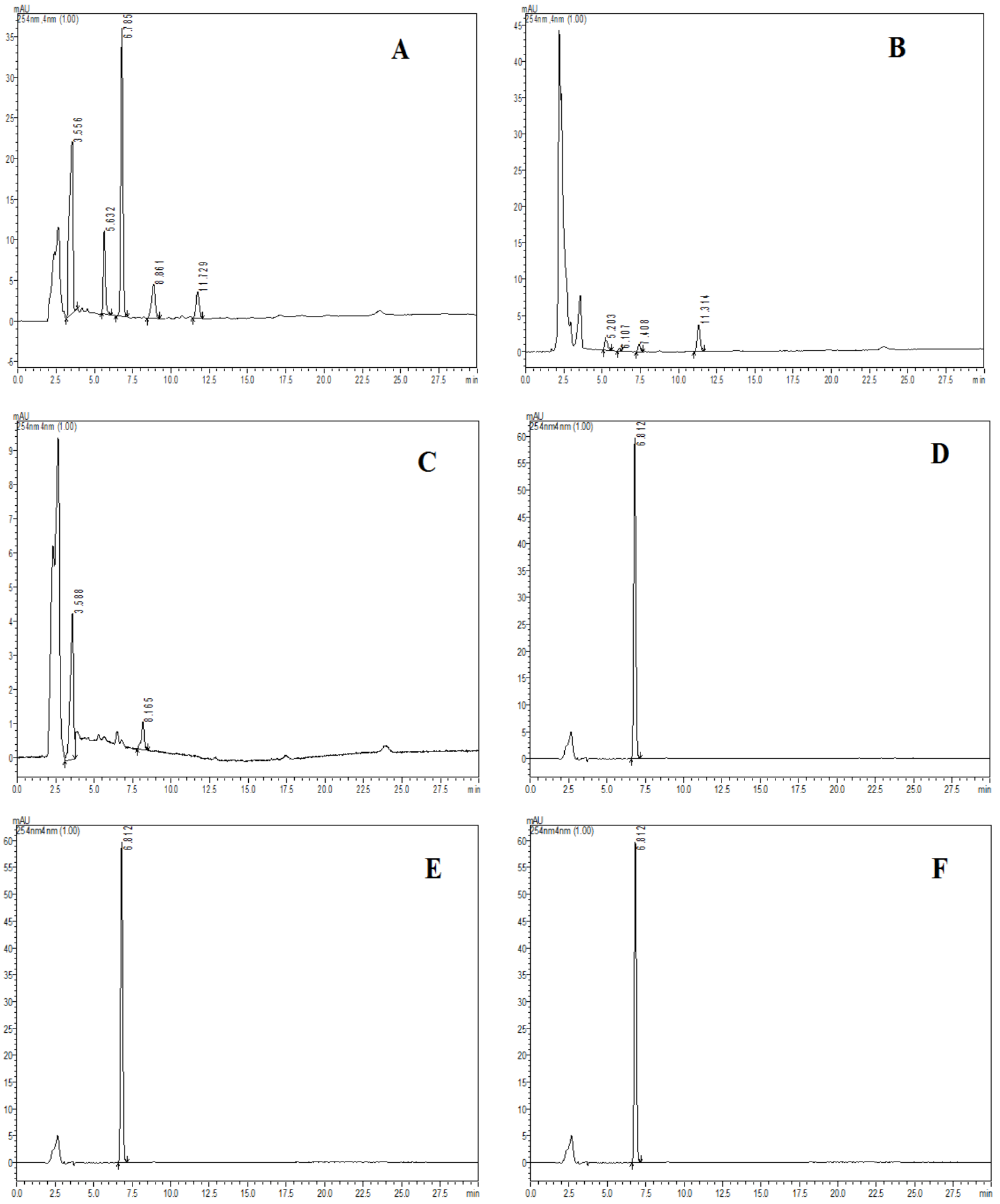

Fig. 3: Chromatograms of (A) Acid treated, (B) Base treated, (C) Oxygen treated, (D) Thermal, (E) Thermal and humidity, (F) Photo degradation samples.

\section{Linearity}

A linear relationship was evaluated across a concentration range $(2-10 \mu \mathrm{g} / \mathrm{mL})$ for $\mathrm{CPT}$ of the analytical procedure in triplicate. The range of concentrations was selected based on 80$120 \%$ of the test concentration (for assay).
Peak area and concentrations were subjected to least square regression analysis to calculate regression equation. The regression coefficient $\left(\mathrm{R}^{2}\right)$ was found to be 0.994 . The data of the calibration curve was given in Table II. 


\section{Precision}

The precision of an analytical method gives information on the random error. It expresses agreement between a series of measurements obtained from multiple sampling of the same homogeneous sample under prescribed conditions. The percentage RSD value for the precision study was found to be below 2 and fulfilled the ICH guidelines criteria (Table II). These results confirm good precision of the method.

\section{Accuracy}

Accuracy was examined by performing recovery studies using standard addition method as the exact impurities are unknown for CPT. The recovery of the added standard to the drug product sample was calculated and it was found to be 99.07100.45 (Table II). These results indicate a good accuracy of the method to that of the labeled claim.

Table II: Validation Data of CPT.

\begin{tabular}{|c|c|c|c|}
\hline \multicolumn{4}{|c|}{ Validation Data of CPT } \\
\hline Linearity $(n=3)$ & $\begin{array}{c}\text { Range } 2-10 \mathrm{ug} / \mathrm{mL} \\
\mathrm{y}=69650 \mathrm{x}-62690 \\
\mathrm{R}=0.999 \\
\mathrm{R}^{2}=0.994\end{array}$ & - & - \\
\hline Accuracy $(n=3)$ & \% Level of Addition & $\begin{array}{c}\text { Mean } \\
\text { Percent } \\
\text { Recovery }\end{array}$ & \% RSD \\
\hline & 75 & 99.5 & 1.01 \\
\hline & 100 & 100.45 & 0.56 \\
\hline & 125 & 99.07 & 0.64 \\
\hline Precision $(n=6)$ & $\begin{array}{l}\text { Average peak area of the } \\
\text { standard sample (\%RSD) }\end{array}$ & & \\
\hline $\begin{array}{c}\text { System } \\
\text { Precision }\end{array}$ & $8190372(0.151)$ & & \\
\hline $\begin{array}{c}\text { Percent Assay } \\
\text { Mean } \pm \text { SD } \\
(n=3)\end{array}$ & $99.64 \pm 0.661$ & - & - \\
\hline
\end{tabular}

\section{Robustness}

As part of the robustness, deliberate changes in the flow rate, wavelength and mobile phase composition were made to evaluate the impact on the method. Retention times were significantly changed with change in the flow rate and mobile phase composition but no change was found with change in wavelength. However, \% assay values were within limits (\%RSD $<2$ ) and these results indicated minor changes in the flow rate and mobile phase composition didn't affected the assay results. The parameters like theoretical plate number, tailing factor \& capacity factor were also found to be within the limits (Table III).

\section{LOD \& LOQ}

LOD and LOQ were calculated from the average slope and standard deviation from the calibration curve. LOD and LOQ for CPT were found to be $0.022 \mu \mathrm{g} / \mathrm{mL}$ and $0.077 \mu \mathrm{g} / \mathrm{mL}$ respectively. These results indicate that the method is sensitive enough to carry out the routine analysis of CPT dosage forms.
Table III: Robustness data for CPT

\begin{tabular}{|c|c|c|c|c|c|}
\hline $\begin{array}{c}\text { Chromatographic } \\
\text { parameters }\end{array}$ & $\begin{array}{l}\text { Retention } \\
\text { time (min) }\end{array}$ & $\begin{array}{c}\text { Theoretical } \\
\text { plates }\end{array}$ & $\begin{array}{l}\text { Capacity } \\
\text { factor }\end{array}$ & $\begin{array}{l}\text { Tailing } \\
\text { factor }\end{array}$ & \% Assay \\
\hline \multicolumn{6}{|c|}{ Flow rate $(\mathrm{mL} / \mathrm{min})$} \\
\hline $0.95(-5 \%)$ & 7.114 & 10540.65 & 1.57 & 1.13 & 101.45 \\
\hline 1 & 6.79 & 11349.39 & 1.56 & 1.13 & 99.88 \\
\hline $1.05(+5 \%)$ & 6.41 & 11362.6 & 1.57 & 1.13 & 98.50 \\
\hline \multicolumn{6}{|c|}{ Wavelength $(\mathrm{nm})$} \\
\hline $253(-1)$ & 6.79 & 11349.34 & 1.56 & 1.13 & 101.35 \\
\hline 254 & 6.79 & 11349.39 & 1.56 & 1.13 & 99.88 \\
\hline $255(+)$ & 6.79 & 11350.68 & 1.56 & 1.13 & 99.14 \\
\hline \multicolumn{6}{|c|}{ Mobile phase } \\
\hline $62: 38$ & 7.54 & 11600.53 & 1.56 & 1.113 & 101.22 \\
\hline $60: 40$ & 6.79 & 11349.39 & 1.86 & 1.13 & 99.88 \\
\hline $58: 32$ & 6.16 & 10540.65 & 1.34 & 1.14 & 101.53 \\
\hline
\end{tabular}

\section{Assay of Formulation}

Since, the CPT tablets were not commercially available; assay of CPT in controlled release tablets (containing $50 \mathrm{mg}$ of CPT) that were prepared in the laboratory was performed. 20 tablets were weighed individually and finely powdered. A powder blend equivalent to $10 \mathrm{mg}$ of CPT was transferred to a $10 \mathrm{~mL}$ volumetric flask containing about $6 \mathrm{~mL}$ of DMSO, sonicated and made up to the mark with the same.

The resulting solution was filtered through $0.45 \mu \mathrm{m}$ nylon membrane filter to obtain a stock solution of $1 \mathrm{mg} / \mathrm{mL}$. It was further diluted with methanol to get the required concentration $(10 \mu \mathrm{g} / \mathrm{mL})$. The solution was injected three times into the column. From the peak area obtained, the content of CPT in the tablets was calculated. The results were given in Table. II. The assay was found to be within the limits, indicating that the present LC conditions can be used for the assay of CPT in different formulations.

\section{Filter Compatibility Study}

Compatibility of $0.45 \mu \mathrm{m}$ nylon and PVDF disposable filters with dissolution samples was studied. The variation in the assay values of the filtered samples when compared to unfiltered standard samples was found to be $0.05 \%$ and $4.36 \%$ with nylon filters and PVDF filters respectively. Thus, it was found that nylon filters were suitable for filtration of dissolution samples and were employed in the study.

\section{Dissolution Sample Analysis}

Dissolution of CPT from in house developed controlled release tablets was performed using USP type-II apparatus (paddle) and samples were analysed using the proposed method. The dissolution profile of the tested formulation was shown in Figure 4.

A controlled release of CPT over a period of $12 \mathrm{~h}$ was obtained with the formulation tested and the present method can be successfully used for the analysis of CPT dissolution samples. 


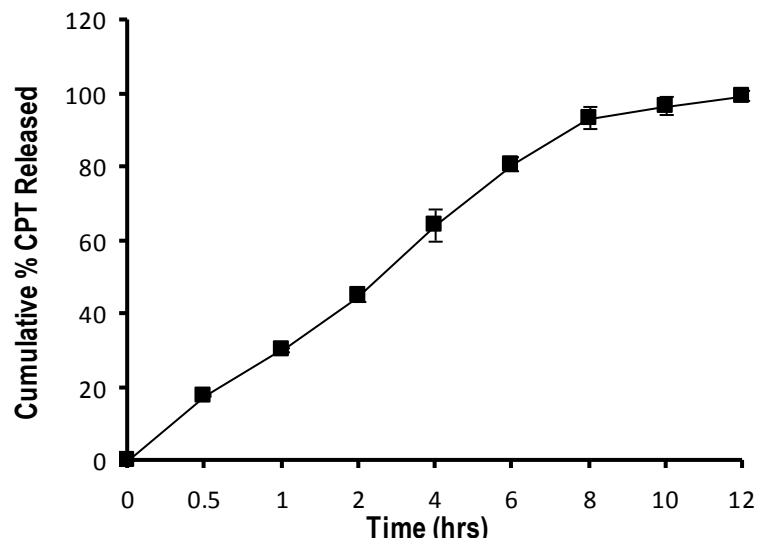

Fig. 4: In vitro dissolution profile of controlled release tablet formulation of CPT

\section{CONCLUSION}

The developed RP HPLC-PDA isocratic method for quantitative determination of CPT is rapid, precise, accurate and selective. The method was completely validated and the data for all method-validated parameters tested were within the limits. The developed method is also stability-indicating, as all degradants were well resolved and can be used for assessing the stability of CPT as a bulk drug and also in formulations. Overall, the developed LC method can be conveniently used for the analysis of CPT in bulk drugs and pharmaceutical dosage forms in quality control department and also dissolution samples.

\section{ACKNOWLEDGEMENTS}

The authors are thankful to Dr. UN Das, Undurti Life Sciences, USA for providing gift sample of Camptothecin and to the Siddhartha Academy of General and Technical education, Vijayawada for providing facilities to carry out the research work.

\section{Financial support and sponsorship: Nil.}

Conflict of Interests: There are no conflicts of interest.

\section{REFERENCES}

Beijnen JH, Rosing H, Ten BH WW, Pinedo HM. HPLC analysis of the antitumor drug Camptothecin and its lactone ring opened form in rat plasma. J Chromatogr, 1993; 617:111- 117.

Blanka Z, Kruszewski S, Ryszard S, Michal C. Deactivation rate of Camptothecin determined by factor analysis of steady-state fluorescence and absorption spectra. Opt Appl, 2006; 36:137- 146.

Chen X, Ji Z, Chen Y. TTD: Therapeutic Target Database. Nucleic Acids Res, 2002; 30: 412- 5.

Deanna LW, Thomas GB. Simple and versatile highperformance liquid chromatographic method for the simultaneous quantitation of the lactone and carboxylate forms of Camptothecin anticancer drugs. J Chromatogr B Biomed Sci Appl, 1997; 691:161- 171.

Feofanov AV, Baranov AV, Fleury F, Riou JF, Nabiev IR, Manfait M. DNA topoisomerase I changes the mode of interaction between camptothecin drugs and DNA as probed by UV-resonance Raman Spectroscopy. J Phys Chem B, 1996; 396:289- 92.

Igor C, Jean MM, Ganesh DS, Jean FR, Michel M. Kinetics of lactone hydrolysis in antitumor drugs of camptothecin series as studied by fluorescence spectroscopy. ,Biochim Biophys Acta 1998; 1379:353- 366.
Indramohan S, Kumaravadivel N, Gnanam R, Vellaikumar S. RP-HPLC analysis for Camptothecin content in Nothapodytes nimmoniana, an endangered medicinal Plant. J Med Plants Res, 2010; 4:255- 259 .

International Conference on Harmonization (ICH) Q2 (R1) Validation of analytical procedures: text and methodology. International Conference on Harmonization, IFPMA, Geneva, Switzerland, 2005.

Jeffrey GS, Louis M. A Reversed-phase HPLC method for determining Camptothecin in plasma with specificity for the intact lactone form of the drug. J Liq Chromatogr, 1991; 14:1779- 1803.

Kruszewski S, and Kruszewska DM. Fluorescence spectroscopy in Camptothecins studies. Acta Phys Pol B, 2010; 118:99- 102.

Marques FF, Da CAL, Aucelio RQ. Laser induced fluorescence and photochemical derivatization of trace determination of camptothecin. Talanta, 2010; 83:256- 61 .

Namdeo AG, Sharma A. HPLC analysis of Camptothecin content in various parts of Nothapodytes foetida collected on different periods. Asian Pac J Trop Biomed, 2012; 2:389- 393.

Paulo M, Mariaterisa M, Sonia P, Mario M, Cosimo P. Metabolite finger printing of Camptotheca acuminata and the HPLC-ESI MS/MS analysis of Camptothecin and related alkaloids. J Pharm Biomed Anal, 2010; 51:405- 415 .

Qing YL, Yuan GZ, Rong ZS, Li PY. Review Camptothecin: Current Perspectives. Curr Med Chem, 2006; 13:1- 19.

Sanna N, Chillemi G, Gontrani L, Grandi A, Mancini G, Castelli S, Zagotto G, Zazza C, Barone V, Desideri A. UV-VIS spectrum of the anti-cancer Camptothecin family drugs in aqueous solution, specific spectroscopic signatures unraveled by a combined computational and experimental study. J Phys Chem B, 2009; 113: 5369-75.

Srimany A, Ifa DR, Naik HR, Bhat V, Cook RG, Pradeep T. Direct analysis of camptothecin from Nothapodytes nimmoniana by desorption electrospray ionization mass spectrometry (DESI-MS). Analyst, 2011; 136:3066- 3068.

Susan MM, Theiny W, Virginiya MFG, Bruno S, Domingos CF. Development and validation of a simple reversed-phase HPLC method for the determination of Camptothecin in animal organs following administration in solid lipid nanoparticles. J Chromatogr B, 2012; 880:100- 107.

Tsakalozou E, Horn J, Leggas M. An HPLC assay for the lipophilic Camptothecin analog AR-67 carboxylate and lactone in human whole blood. Biomed Chromatogr, 2010; 24:1045- 51.

Underberg WJ, Gossan RM, Smith BR, Bejnen JH. Equilibrium kinetics of the new experimental anti-tumour compound SK\&F 104864- A in aqueous solution. J Pharm Biomed Anal, 1990; 8:681- 683.

Venkateshwarlu A, Rama Rao AV, Khagga M. Development and Validation of Stability Indicating LC Method for 10Hydroxycamptothecin. Am J Anal Chem, 2012; 3:470- 477.

Vidya D, Ramesh TS, Gaurang P, Vijay G, Onkar D. HPTLC quantification of Camptothecin in Nathopodytes foetida (wight) Sleumer stem powder. J Planar Chromatogr - Mod TLC, 2007; 20:131- 133.

Wall ME, Wani MC. Camptothecin: Discovery to Clinic. Ann N Y Acad Sci, 1996; 803:1- 12

Wall ME, Wani MC, Cook CE, Palmer KH, McPhail AT, Sim GA. The isolation and structure of Camptothecin, a novel alkaloidal leukemia and tumor inhibitor from Camptotheca acuminate. J Am Chem Soc, 1966; 88:3888- 3890.

Yong XZ, Jian QG, Hai LQ, Hai LC, Wen QL. Development and validation of a sensitive reversed-phase HPLC method to determine intracellular accumulation of hydroxycamptothecin. J Pharm Biomed Anal, 2006; 41:1007- 1010.

How to cite this article:

Nalluri BN, Valluru S, Bonthu C. Development of Validated Stability Indicating RP-HPLC-PDA Method for Camptothecin Analysis. J App Pharm Sci, 2016; 6 (09): 140-146. 